http://dx.doi.org/10.1590/0370-44672018730192

\author{
Frederico Carlos Maciel Thom ${ }^{1,5}$ \\ https://orcid.org/0000-0003-2446-4136 \\ Joao Roberto Bastos Zoghbi ${ }^{2,6}$ \\ https://orcid.org/0000-0002-0849-7678 \\ Marcílio Sousa da Rocha Freitas ${ }^{3,7}$ \\ https://orcid.org/0000-0003-4664-5368 \\ Geraldo Rossoni Sisquini ${ }^{4,8}$ \\ https://orcid.org/0000-0001-8275-6343 \\ ${ }^{1}$ Petrobras (SBS/BENS/MEE/GC), \\ Gestão de Contratos, \\ Vitória - Espírito Santo - Brasil. \\ ${ }^{2}$ Petrobras (UO-ES/ENGP/EEE), \\ Engenharia de Equipamentos Estáticos, \\ Vitória - Espírito Santo - Brasil.
}

${ }^{3}$ Universidade Federal de Ouro Preto - UFOP, Escola de Minas, Departamento de Engenharia Civil, Ouro Preto - Minas Gerais - Brasil.

${ }^{4}$ Universidade Federal do Espirito Santo - UFES, Departamento de Engenharia Mecânica,

Vitória - Espírito Santo - Brasil.

E-mails: ${ }^{5}$ thom_vix@yahoo.com.br,

6zoghbi.br@gmail.com, ${ }^{7}$ freitas.marcilio@gmail.com, 8geraldo.sisquini@ufes.br

\section{Dynamic risk calculation model applied to gas compressors}

Abstract

The present article proposes to apply a Risk-Based Maintenance methodology in a gas compression system. This risk calculation is based on a semi-quantitative mathematical model that uses the interdependence of process variables and predictive maintenance data applied in a Condition-Based Maintenance methodology, in order to obtain the calculation of the dynamic risk. This promotes a review of maintenance and reliability strategies proactively in real time. The dynamic risk applied to the system involves the interface of predictive maintenance and process variables with the reliability and risk analyses of the system. This value, which is associated with the financial aspects, safety, people and environment, can be compared to the tolerable risk of production plant operation, providing operation or maintenance decisions. An example demonstrates the integration of process and maintenance data using this model methodology for a gas compression system. This framework can be applied to evaluate the integrity of systems, providing critical risk-based information for the maintenance and operation teams, assisting then in the mitigation of failures in the production systems.

Keywords: condition-based management, risk-based management, asset management, dynamic risk.

\section{Introduction}

An unavailable gas plant results in revenue loss for any industry. Considering health, safety and ecological (HSE) principles, the main systems or equipment must be reliable and secure, so their integrity must be assured. For this purpose, an integrity platform program should be used, but must be economical in order to ensure production with good financial health and HSE policy requirements fulfilled. This is the way Asset Management guides industry.
At first, this study follows the ISO 55000 (2014) standard, considering that Asset Management values target realization of the organization economically. This evaluation depends on the main mission regarding objectives, characteristics 
and management of the organization, together with the needs and expectations of all parties involved. For this purpose, herein is presented a risk-based maintenance model that can be used as a management integrity tool for minimizing costs applied to three redundant compressor systems. This model is a semi-quantitative approach based on API 581 (2008) risk methodology that uses online plant process alarms, shutdowns and historical maintenance predictive data to constantly enhance consequences, combined with calculated probability failure based on the Weibull model using daily maintenance data as input.

Asset Management uses Risk-Based Inspection (RBI) and Condition-Based Maintenance (CBM) as pillars for its implementation, as shown in Kardec et al. (2014), who recommend this methodology as state-of-art that improves production results ranking at a high and necessary reliability level. Both in international standards used in oil and gas industry and in academic investigation, this theme, Risk and Condition-Based Maintenance, has matured usage in several industrial areas and literature confirms this, as shown as follows.

Risk-Based Maintenance is very mature in the industries and consolidated in their international Organizations, as ABS (American Bureau of Shipping), API (American Petroleum Institute),
BS (British Standards), IEC (International Electrotechnical Commission), ISA (Instrument Society of America) and ISO (International Organization for Standardization). It can be seen in API 581 (2008), and these forums motivate integration of this practice with other strategies, such as Reliability Centered Maintenance (RCM), as proposed by ABS (2003) and ABS (2004). Arunraj \& Maiti (2007) show an investigation on the state-of-art of RBI, and Hu et al. (2009), show the implementation of this strategy with a model applied to a downstream industry and its gains. Qingfeng et al. (2011) show the necessity to integrate models as RAM (Reliability, Availability and Maintainability) and classify a time based risk indicator, introducing transient or online information in order to adjust the preventive and corrective actions of an industrial process.

Another strategy adopted in asset management is CBM (Condition-Based Maintenance), whose concepts and implementation are presented in ISO 13374-1 (2003). Padmanabhan (2008) proposes the use of CBM but employs real time data in order to optimize its results for maintenance and production. Considering the upstream industry, Telford et al. (2011) show the gains of adopting CBM using process data not only to control the process, but to make failure diagnosis as an active remote monitoring.

Ahmad \& Kamaruddin (2012) presented a huge state-of-art analysis of CBM implemented in distinct industry processes, confirming the consolidation of this maintenance strategy as the essential core of asset management, supporting production and maintenance decision. The work of Gowid et al. (2016) confirm the integration of process data supporting maintenance diagnosis, considering the recent nonintrusive instruments and data treatment technologies.

The state-of-art presented shows that the maintenance strategies, RBM and CBM, are essential to asset management, as defined in their implementation by ISO 55000 (2014). These strategies are well consolidated in literature as discussed above and in distinct kinds of industries as shown in their normalized standards.

In this article, a model is presented that combines Risk-Based Maintenance (RBM) and Condition-Based Maintenance (CBM) methodologies. The developed model integrates distinct maintenance and process data as a platform, that permits evaluation of an actual failure risk of a production system, as shown in Figure 1. More details and developments can be seen in Thom (2018), and specifically in this area, it is important to see Khan \& Haddara (2003).

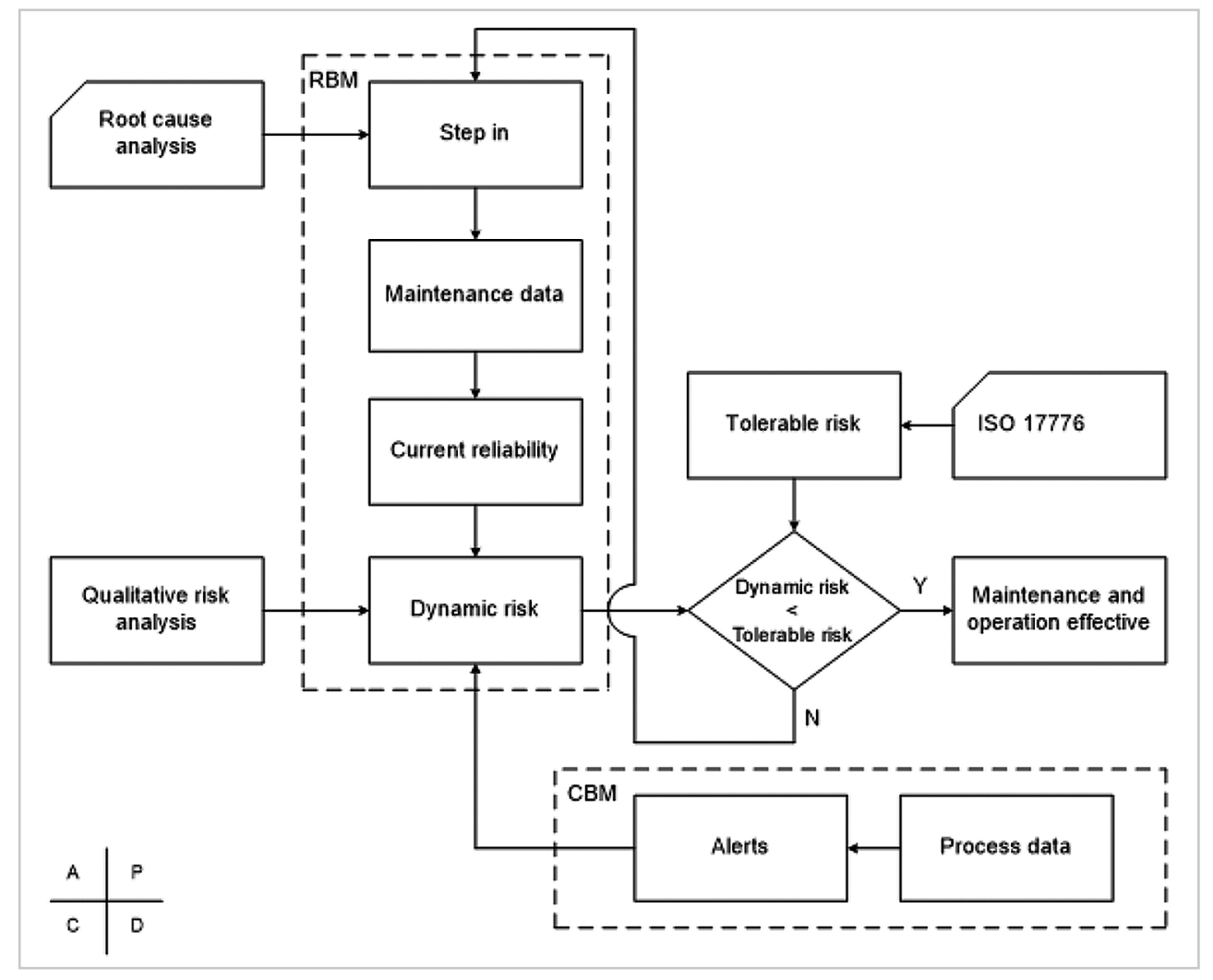

Figure 1 - Dynamic risk assessment. 


\section{Proposed model}

As pointed out, this proposed model is a RBM approach that consists of evaluating the historical quantita- tive failure probability combined with its qualitative consequence, using the concept of risk evaluation, as defined in API 580 (2009), for each element according to the level of taxonomy in the system $(\mathrm{i}, \mathrm{j}, \mathrm{k})$ :

$$
\text { Risk }_{\mathrm{i}, \mathrm{j}, \mathrm{k}}=(\text { Probability of Failure })_{\mathrm{i}, \mathrm{j}, \mathrm{k}} \cdot(\text { Consequence of Failure })_{\mathrm{i}, \mathrm{j}, \mathrm{k}}
$$

where from API 581 (2008), Probability of Failure, PoF, likelihood of failure occurs of each

\subsection{Scope}

The scope adopted to develop the proposed model is a redundant gas compressor system. It is formed by three moto-compressors, which are modeled in this study, using ABNT NBR ISO 14224 (2011) taxonomies to define and catego- $(\mathrm{i}, \mathrm{j}, \mathrm{k})$, and Consequence of Failure, $\mathrm{CoF}$, value that ranks effects of each $(\mathrm{i}, \mathrm{j}, \mathrm{k})$ element failure.

rize the motor and compressor systems, along with subsystems, such as lubricant, sealing (e.g. equipment, pumps, valves); according to the illustrated taxonomy tree, $(i, j, k)$, where the levels are: (i) subsystem, (j) equipment and (k) component, as seen in Figure 2.

This gas compressor system tree adopted categorization which has been used as input to cluster failure data of the compressor system, detailed in the next topic, as labeled in Table 1.

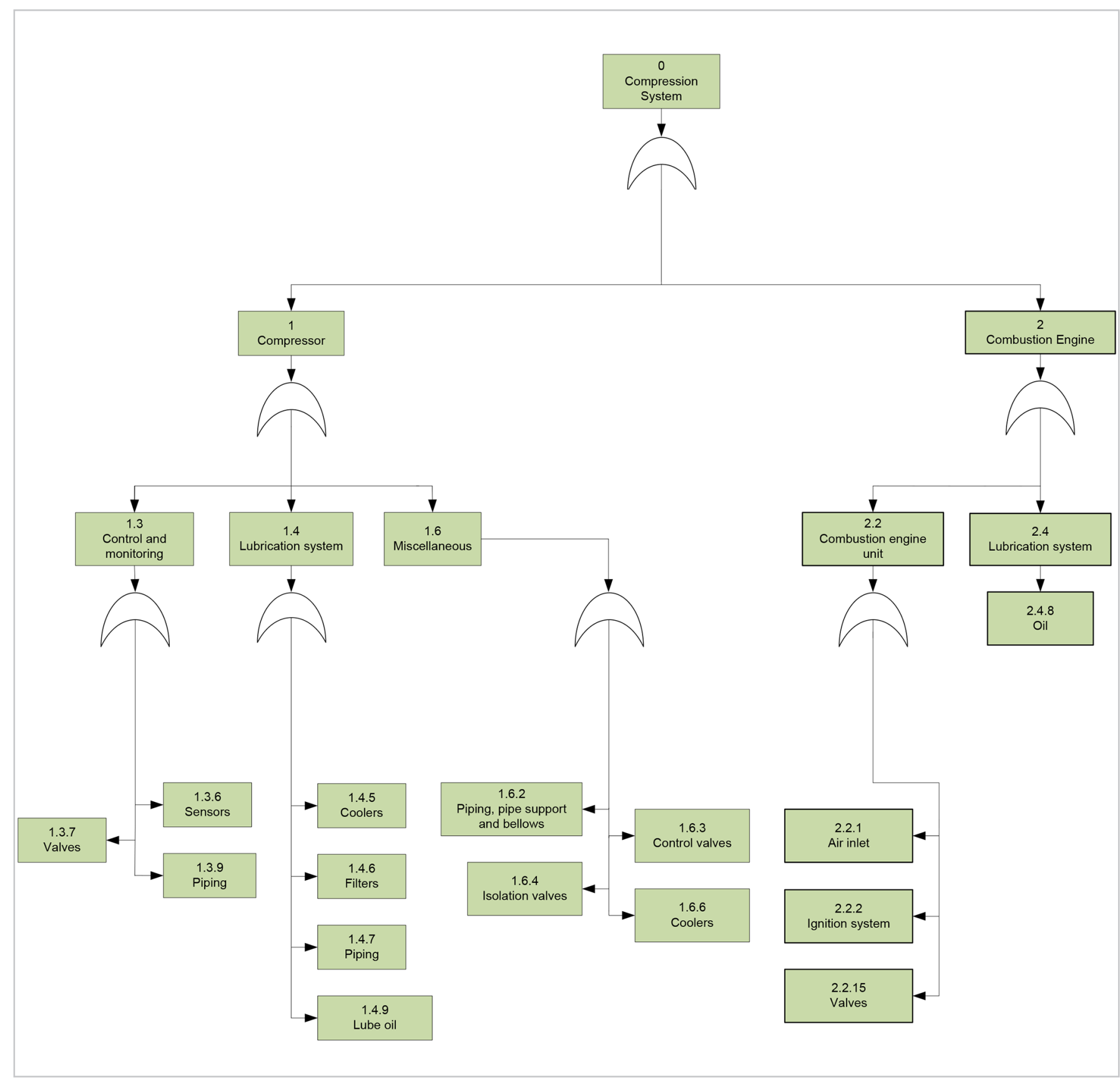

Figure 2 - Taxonomy tree of the moto-compressor for algebra in the calculation of the dynamic risk. 
Table 1 - Historical failures data

\begin{tabular}{lc}
\hline Date of note & Description \\
\hline $09 / 01 / 2016$ & PSV calibration \\
$09 / 01 / 2016$ & PSV calibration \\
$09 / 05 / 2016$ & Dubious instrument indication \\
$09 / 06 / 2016$ & Dubious instrument indication \\
$09 / 22 / 2016$ & PSV calibration \\
$09 / 22 / 2016$ & PSV calibration \\
$09 / 22 / 2016$ & PSV calibration \\
$09 / 22 / 2016$ & PSV calibration \\
$09 / 26 / 2016$ & Instrument presenting fault \\
$09 / 29 / 2016$ & Install thermal protection on motor \\
$09 / 30 / 2016$ & Check and clean vessel \\
$10 / 04 / 2016$ & Adequate descriptive alarm instrument \\
$10 / 04 / 2016$ & Adequate descriptive alarm instrument \\
$10 / 10 / 2016$ & Safety valve defect \\
$10 / 10 / 2016$ & Safety valve defect \\
$10 / 24 / 2016$ & Pump with damaged conduit \\
$10 / 24 / 2016$ & Pump with damaged conduit \\
$10 / 24 / 2016$ & Loose ground motor \\
\hline
\end{tabular}

\subsection{Failure probability}

This historical maintenance data (six years period), with the failure events and the date of their occurrences for each taxonomy level (i,j,k), were processed considering their time to failure and submitted to the Weibull regression model, based on probability of failure function, Eq.2, using MLE - Maximum Likelihood Estimation method, to obtain $\beta$, shape parameter, and $\eta$, life parameter, for the failure prob-

$$
F(t)=\int_{-\infty}^{t} f(t) d t=1-e^{-(t / \eta)^{\beta}}
$$

ability time function and other reliability correlations, such as MTTF (Mean Time to Failure), for each failure component of the redundancy compressor system, as shown in Table 2.
This regression treatment shows the most unreliable elements of these gas compressor systems, such as 1.3.6 (sensors), that contribute significantly to machine downtime.

Table 2 - Weibull parameters of the $\operatorname{PoF}(t)$ in the considered period of some moto-compressor

\begin{tabular}{cccccc}
\hline Taxonomy & $\beta$ & $\eta$ & Failures quantity & MTTF (days) & $\mathrm{R}^{2}$ \\
\hline 1.3 .6 & 0.83863 & 55.105758 & 53 & 41.430878 & 0.986843 \\
1.3 .7 & 0.91238 & 297.920663 & 11 & 207.447688 & 0.975707 \\
1.3 .9 & 0.549286 & 195.669408 & 12 & 333.781714 & 0.964438 \\
1.4 .5 & 1.431561 & 763.231719 & 4 & 554.632297 & 0.967694 \\
1.4 .6 & 1.019573 & 721.720837 & 4 & 572.777309 & 0.970101 \\
1.4 .7 & 0.713635 & 319.158207 & 6 & 396.779299 & 0.956047 \\
1.4 .9 & 1.056944 & 531.599125 & 5 & 433.432539 & 0.959118 \\
1.6 .2 & 0.806672 & 139.01324 & 15 & 146.791308 & 0.94797 \\
1.6 .3 & 2.338904 & 544.495442 & 4 & 482.480076 & 0.973228 \\
1.6 .4 & 0.697804 & 240.13742 & 9 & 274.398091 & 0.942751 \\
1.6 .6 & 0.790443 & 180.903555 & 12 & 190.854023 & 0.972153 \\
2.2 .1 & 1.589903 & 531.93405 & 4 & 477.19989 & 0.863581 \\
2.2 .2 & 1.173115 & 225.025459 & 11 & 195.207002 & 0.987523 \\
2.2 .15 & 0.972462 & 214.328263 & 11 & 198.884883 & 0.889003 \\
2.4 .8 & 0.728703 & 270.896041 & 7 & 330.533618 & 0.944534 \\
\hline
\end{tabular}




\subsection{Consequence assessment}

In order to obtain the consequence of each elemental failure $(i, j, k)$ of the system, $\operatorname{CoF}(i, j, k)$, a Failure Mode Effect Analysis (FMEA) is done as proposed in IEC 60812 (2006), for each failure data considering their addressed taxonomy [subsystem (i), equipment (j) and component $(\mathrm{k})]$ and finally their potential failure effects on Health, Safety and Environment (HSE) besides financial effects, ranking this qualitative information into the effect of the quantitative factor in accordance with ISO 13623 (2017). Then, the maximum value of $\mathrm{CoF}_{i, j, k}$ (limited to unit) is obtained from the numerically attributed potential fail- ure effect columns and related to aspects of Safety, Environment and Finance, as shown in Table 3.

However, to classify the failure mode for each element $(i, j, k)$ and evaluate quantitatively their effects, the model treatment considers OREDA (2002) taxonomy nomenclature.

Table 3 - Consequence of failure evaluation for FMEA gas system items

\begin{tabular}{|c|c|c|c|c|c|c|c|c|c|c|}
\hline \multirow{3}{*}{ Subsystem } & \multirow{3}{*}{ Equipment } & \multirow{3}{*}{ Component } & \multirow{3}{*}{ Failure mode } & \multirow{3}{*}{$\begin{array}{c}\text { Class } \\
\text { (OREDA) }\end{array}$} & \multicolumn{4}{|c|}{ Potential failure effects } & \multirow{3}{*}{$\begin{array}{c}\text { Potential } \\
\text { causes / } \\
\text { Failure } \\
\text { mechanisms }\end{array}$} & \multirow{3}{*}{$\begin{array}{l}\text { Recommended } \\
\text { actions }\end{array}$} \\
\hline & & & & & \multirow{2}{*}{ Operational } & \multicolumn{3}{|c|}{ Non operational (CoF) } & & \\
\hline & & & & & & Safety & Environment & Finance & & \\
\hline \multirow[t]{14}{*}{ 1. Compressor } & $\begin{array}{l}\text { 1.1 Power } \\
\text { transmission }\end{array}$ & $\begin{array}{l}\text { 1.1.1 Gearbox } \\
\text { / variable drive }\end{array}$ & Breakdown & BRD & $\begin{array}{l}\text { Equipment doesn't } \\
\text { work }\end{array}$ & 0.1 & 0.1 & 0.5 & Damaged & Visual inspection \\
\hline & & & $\begin{array}{l}\text { External Leakage } \\
\text { - Utility Medium }\end{array}$ & ELU & Abnormal functioning & 0.1 & 0.1 & 0.1 & Oil leak & Visual inspection \\
\hline & & & Noise & $\mathrm{NOI}$ & Sound disturbance & 0.1 & 0.1 & 0.1 & $\begin{array}{l}\text { Locked up or } \\
\text { misalignment }\end{array}$ & Visual inspection \\
\hline & & & Overheating & $\mathrm{OHE}$ & Drop of income & 0.1 & 0.1 & 0.5 & Locked up & $\begin{array}{c}\text { Detective } \\
\text { maintenance }\end{array}$ \\
\hline & & & $\begin{array}{l}\text { Structural } \\
\text { Deficiency }\end{array}$ & STD & Abnormal functioning & 0.1 & 0.1 & 0.1 & $\begin{array}{l}\text { Fatigue } \\
\text { or wear }\end{array}$ & Visual inspection \\
\hline & & & Vibration & VIB & Decrease in income & 0.1 & 0.1 & 0.5 & $\begin{array}{l}\text { Internal } \\
\text { anomaly }\end{array}$ & $\begin{array}{c}\text { Measurement } \\
\text { of vibration } \\
\text { analysis and } \\
\text { visual inspection }\end{array}$ \\
\hline & & 1.1.2 Bearings & Breakdown & BRD & Bearing inoperative & 0.1 & 0.1 & 0.5 & Damaged & Visual inspection \\
\hline & & & Noise & $\mathrm{NOI}$ & Sound disturbance & 0.1 & 0.1 & 0.1 & $\begin{array}{l}\text { Locked up or } \\
\text { misalignment }\end{array}$ & Visual inspection \\
\hline & & & $\begin{array}{l}\text { Structural } \\
\text { Deficiency }\end{array}$ & STD & Abnormal functioning & 0.1 & 0.1 & 0.1 & $\begin{array}{l}\text { Fatigue } \\
\text { or wear }\end{array}$ & Visual inspection \\
\hline & & & Vibration & VIB & Decrease in income & 0.1 & 0.1 & 0.5 & $\begin{array}{l}\text { Internal } \\
\text { anomaly }\end{array}$ & $\begin{array}{c}\text { Measurement } \\
\text { of vibration } \\
\text { analysis and } \\
\text { visual inspection }\end{array}$ \\
\hline & & $\begin{array}{l}\text { 1.1.3 Coupling } \\
\text { to the driver }\end{array}$ & Breakdown & BRD & $\begin{array}{l}\text { Non-motion } \\
\text { transmission }\end{array}$ & 0.1 & 0.1 & 0.5 & Damaged & Visual inspection \\
\hline & & & Noise & $\mathrm{NOI}$ & Sound disturbance & 0.1 & 0.1 & 0.1 & $\begin{array}{l}\text { Locked up or } \\
\text { misalignment }\end{array}$ & Visual inspection \\
\hline & & & $\begin{array}{l}\text { Structural } \\
\text { Deficiency }\end{array}$ & STD & Abnormal functioning & 0.1 & 0.1 & 0.1 & $\begin{array}{l}\text { Fatigue } \\
\text { or wear }\end{array}$ & Visual inspection \\
\hline & & & Vibration & VIB & Decrease in income & 0.1 & 0.1 & 0.5 & $\begin{array}{l}\text { Internal } \\
\text { anomaly }\end{array}$ & $\begin{array}{c}\text { Measurement } \\
\text { of vibration } \\
\text { analysis and } \\
\text { visual inspection }\end{array}$ \\
\hline
\end{tabular}

\subsection{Dynamic enhancer factor}

In order to integrate the CBM philosophy in this model, that combines maintenance and historical process data, along with alarms and triggered events in the control and integrity systems, place all these data into an integrated platform that computes abnormal maintenance results, classified and evaluated by Dynamic Enhancer Factors, as follows:

a) Alarm Process Condition Enhancer $\left(\mathrm{I}_{\mathrm{A}}\right)$, see Table 4 , that correlates measured sensor values of the process control (REAL) with their alarms set [low $\left(\mathrm{SET}_{\mathrm{L}}\right)$ or high $\left(\mathrm{SET}_{\mathrm{H}}\right)$ limits], during equipment operation time that are related to each taxonomy $(\mathrm{i}, \mathrm{j}, \mathrm{k})$ investigated.

b) Interlocking Enhancer $\left(\mathrm{I}_{\mathrm{I}}\right)$, see Table 5, evaluates mergers of limit zones of control that force equipment shutdown, that correlates measured sensor values (REAL) of process interlocking with their triggers sets [low low $\left(\operatorname{SET}_{\mathrm{LL}}\right)$ or high high $\left(\mathrm{SET}_{\mathrm{HH}}\right)$ limits], during equipment operation time that are related to each taxonomy $(i, j, k)$ investigated. c) Predictive Maintenance Intensifier $\left(\lambda_{n c}\right)$ is a modified accumulated failure rate based on non-conformities counting identified in reports of predictive inspections, as lubricant's contaminants or abnormal vibration data (number of events), that evidences the failure evolution of system components, as the example of Table 6 , that shows some collected predictive inspections with non-conformity events, converted to accumulated rate during the machine period of time operation. 
Table 4 - Example of alarm enhancer factor calculation using pressure sensor data

\begin{tabular}{cccccc}
\hline Date & Value indicated & SET $_{H}$ & SET $_{L}$ & $I_{A}=\left(\frac{R E A L}{S E T_{H}}\right)\left(\frac{R E A L}{S E T_{H}}\right) \leq 1 \Rightarrow 1$ \\
\hline $04 / 01 / 2012$ & 69.18 & 71 & 64 & 0.9744 & 1 \\
$04 / 02 / 2012$ & 71.62 & 71 & 64 & 1.009 & 1.009 \\
$04 / 03 / 2012$ & 71.89 & 71 & 64 & 1.013 & 1.013 \\
$04 / 04 / 2012$ & 67.78 & 71 & 64 & 0.9546 & 1 \\
$04 / 22 / 2012$ & 70.8 & 71 & 64 & 0.9972 & 1 \\
$04 / 23 / 2012$ & 73.5 & 71 & 64 & 1.035 & 1 \\
$04 / 24 / 2012$ & 69.73 & 71 & 64 & 0.9821 & 1 \\
\hline
\end{tabular}

Table 5 - Example of interlocking enhancer factor calculation using pressure sensor data

\begin{tabular}{cccccc}
\hline Date & Value indicated & SET $_{\mathrm{HH}}$ & $\mathrm{SET}_{\mathrm{LL}}$ & $I_{I}=\left(\frac{R E A L}{S E T_{H H}}\right)\left(\frac{R E A L}{S E T_{H H}}\right) \leq 1 \Rightarrow 1$ \\
\hline $01 / 30 / 2012$ & 66.91 & 74 & 62 & 0.904 & 1 \\
$01 / 31 / 2012$ & 73.73 & 74 & 62 & 0.996 & 1 \\
$02 / 01 / 2012$ & 67.79 & 74 & 62 & 0.916 & 1 \\
$02 / 02 / 2012$ & 67.77 & 74 & 62 & 0.916 & 1 \\
$02 / 03 / 2012$ & 76.09 & 74 & 62 & 1.028 & 1.028 \\
$02 / 04 / 2012$ & 67.74 & 74 & 62 & 0.915 & 1 \\
$02 / 11 / 2012$ & 67.11 & 74 & 62 & 0.907 & 1 \\
$02 / 12 / 2012$ & 73.65 & 74 & 62 & 0.995 & 1 \\
\hline
\end{tabular}

Table 6 - Example of abnormal events counting from predictive maintenance and event enhancer calculation

\begin{tabular}{ccccc}
\hline Date & Number of events & Accumulated amount & Accumulated rate & Accumulated rate +1 \\
\hline $01 / 12 / 2010$ & 0 & 0 & 0 & 1 \\
$02 / 05 / 2012$ & 0 & 0 & 0 & 1 \\
$03 / 05 / 2012$ & 2 & 2 & 0.0039 & 1.004 \\
$04 / 05 / 2012$ & 0 & 2 & 0.0039 & 1.004 \\
$08 / 11 / 2012$ & 0 & 2 & 0.0028 & 1.003 \\
$09 / 11 / 2012$ & 4 & 6 & 0.0085 & 1.009 \\
$11 / 11 / 2012$ & 0 & 6 & 0.0084 & 1.008 \\
\hline
\end{tabular}

These three enhancer factors discussed above allow the model to incorporate and update the integrity con-

\subsection{Dynamic risk evaluation}

Considering the gas system adopted as scope for the implementation of this proposed semi-quantitative model, which integrates maintenance, perfor- dition of the gas system, using discrete data of its abnormal events of maintenance and process during its operation, in order to obtain the proposed dynamic risk evaluation.

$$
\operatorname{Risk}_{\text {dynamic }}(t)=\left\{\left[\operatorname{Po}_{i, j, k}(t) \cdot \operatorname{Co}_{i, j, k} \cdot I_{A_{i, j, k}}(t) \cdot I_{I_{i, j, k}}(t)\right] \cdot\left[\lambda_{n c}(t)+1\right]_{i}\right\}
$$




\section{Results}

The dynamic risk model previously discussed was used to evaluate the gas compression systems presented in the scope item, based on their six-year process and maintenance data. The Table 7 demonstrates a one-day system risk evaluation that points out the bad actors as example.

Table 7 - Gas compressor system dynamic risk (10/30/2016).

\begin{tabular}{|c|c|c|c|c|c|c|c|}
\hline \multirow{2}{*}{ Subsystem } & \multirow{2}{*}{ Equipment } & \multirow{2}{*}{ Component } & \multirow{2}{*}{ Taxonomy } & \multirow{2}{*}{$\beta$} & \multirow{2}{*}{$\eta$} & \multicolumn{2}{|c|}{ Obtained on $10 / 30 / 2016$} \\
\hline & & & & & & Probability of failure & Dynamic risk \\
\hline \multirow[t]{11}{*}{ Compressor } & Control and monitoring & Sensors & 1.3 .6 & 0.8386 & 55.106 & 0.992417983 & 0.49896571 \\
\hline & & Valves & 1.3 .7 & 0.9124 & 297.921 & 0.699873712 & 0.7037619 \\
\hline & & Piping & 1.3 .9 & 0.5493 & 195.669 & 0.75546904 & 0.07596661 \\
\hline & Lubrication system & Coolers & 1.4 .5 & 1.432 & 763.232 & 0.746961874 & 0.07511117 \\
\hline & & Filters & 1.4 .6 & 1.020 & 721.721 & 0.39288202 & 0.19753235 \\
\hline & & Piping & 1.4 .7 & 0.7136 & 319.158 & 0.887288527 & 0.08922179 \\
\hline & & Lube oil & 1.4 .9 & 1.057 & 531.599 & 0.489346112 & 0.24603235 \\
\hline & Miscellaneous & $\begin{array}{l}\text { Piping, pipe } \\
\text { support and } \\
\text { bellows }\end{array}$ & 1.6 .2 & 0.8067 & 139.013 & 0.886805215 & 0.89173191 \\
\hline & & Control valves & 1.6 .3 & 2.339 & 544.495 & 0.324566199 & 0.32636934 \\
\hline & & Isolation valves & 1.6 .4 & 0.6978 & 240.137 & 0.737975777 & 0.74207564 \\
\hline & & Coolers & 1.6 .6 & 0.7904 & 180.904 & 0.915451288 & 0.46026856 \\
\hline \multirow[t]{4}{*}{$\begin{array}{c}\text { Combustion } \\
\text { Engine }\end{array}$} & Combustion engine unit & Air inlet & 2.2 .1 & 1.590 & 531.934 & 0.009752034 & 0.0050837 \\
\hline & & Ignition system & 2.2 .2 & 1.173 & 225.026 & 0.019754444 & 0.01029792 \\
\hline & & Valves & 2.2 .15 & 0.9725 & 214.328 & 0.04003975 & 0.04174515 \\
\hline & Lubrication system & Oil & 2.4 .8 & 0.7287 & 270.896 & 0.396329173 & 0.20660493 \\
\hline
\end{tabular}

The analysis of the model's results presents some aspects that must be highlighted:

a) This model can be used to investigate the behavior of the individual risk of the systems, their subsystems (motor and compressor) and their critical elements or bad actors (e.g. piping, pipe support and bellows, 1.6.2 taxonomy);

b) This model shows its main goal by integrating process and mainte- nance data, and providing a supportive decision to system operators in order to mitigate failures, enhancing plant safety and production, as a data platform that works as a risk monitoring tool (see Figure 3).

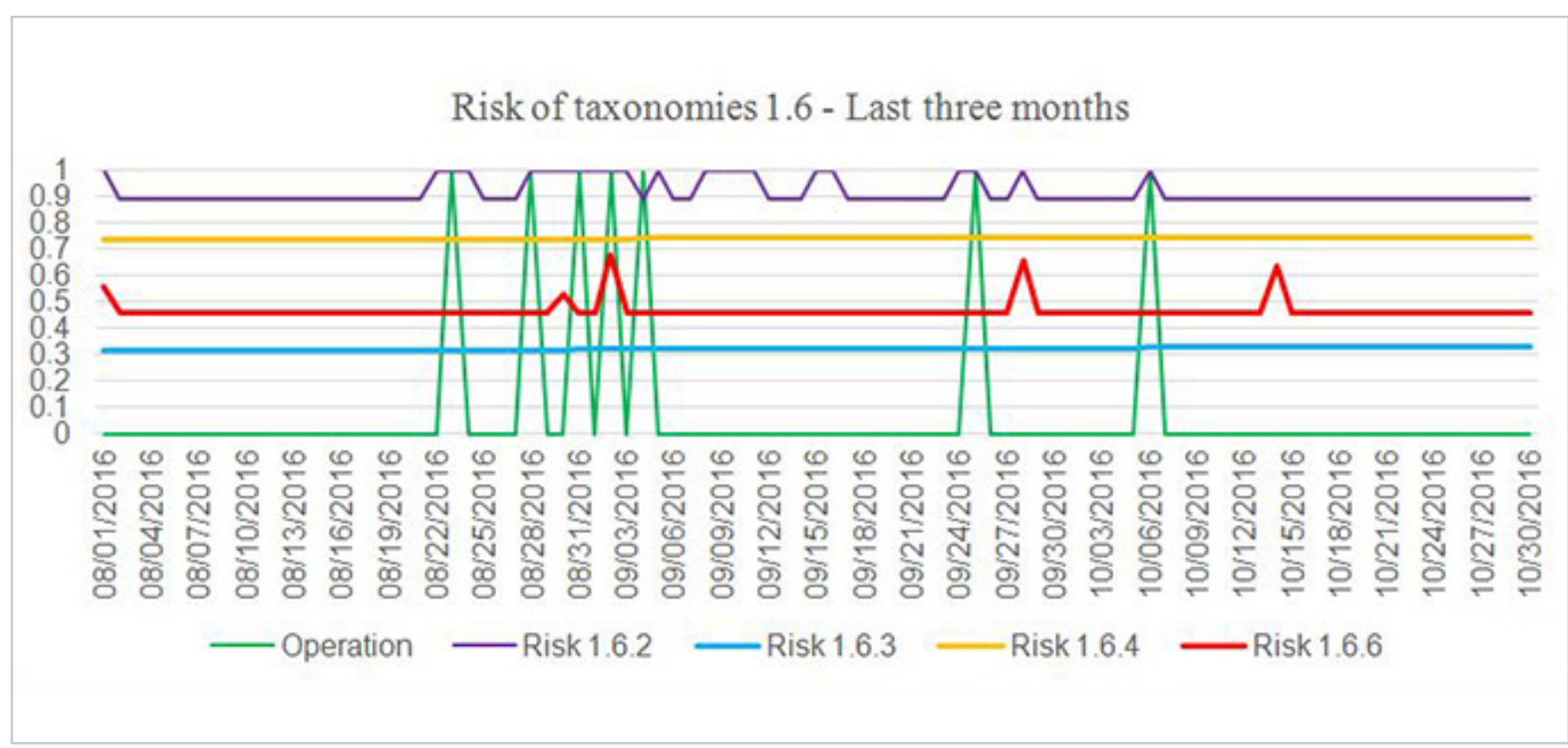

Figure 3 - Graph of dynamic risk in taxonomies 1.6.2 (Piping, pipe support and bellows), 1.6.3 (Control valves), 1.6.4 (Isolation valves) and 1.6.6 (Coolers) of the miscellaneous in the compressor for the period from 08/01/2016 to 10/30/2016. 


\section{Conclusions}

This article reviewed the literature dedicated to Risk-Based Maintenance and Condition-Based Maintenance to obtain the state of art dedicated to these methodologies, especially those articles based on modeling in order to support the developed model presented herein. The investigated state of art shows that RBM and CBM methodologies, used as maintenance strategies, are well consolidated in the oil and gas industries, confirmed in practice and supported by international organization standards, such as ABS, API, BS, ISA and ISO. The risk maintenance quantitative and semi-quantitative models presented in literature demonstrated the integration of failure data correlation with their consequences to financial and HSE aspects of an organization.

Through the concepts of Risk-Based Maintenance of API 580 (2009), a model for a redundant gas compression system was developed. It uses a Weibull fault distribution to correlate historical maintenance data, integrated with its financial and HSE consequences, considering management concepts of assets and risk assessment. It is improved with intensifying factors influenced by predictive maintenance and plant data (emergency and control), transforming this algorithm into a Dynamic Risk Model.

The bad actors emerge from the subsystem and their elements as a result of the correlating failure data process to three redundant gas compression systems adopted as the scope of this study. The main contribution presented in this work is that the model continuously evaluates the integrity of these systems, furnishing the maintenance and operation teams with critical information based on risk, e.g. abnormal vibration detected in oil pump. This would require priority for the mitigation of this failure, proving the model to be potentially applicable to production systems.

Then, analysis of the results demonstrates that the developed risk evaluation model is a maintenance and process integration platform that can be used as a continuous risk-monitoring tool, because of the use of the Weibull correlation based on time and the dynamic enhancer factors incorporated in the model.

\section{Acknowledgements}

The authors are grateful to CAPES, CNPq, FAPEMIG, PETROBRAS, UFES,
UFOP and UFRJ for the support received to carry out this research.

\section{References}

ASSOCIAÇÃO BRASILEIRA DE NORMAS TÉCNICAS. ABNT NBR ISO 14224: indústrias de petróleo e gás natural - Coleta e intercâmbio de dados de confiabilidade e manutenção para equipamentos. Rio de Janeiro: ABNT, 2011.

AMERICAN BUREAU OF SHIPPING. Guide for surveys based on reliability-centered maintenance. Houston: ABS, December, 2003.

AMERICAN BUREAU OF SHIPPING. ABS 0120 : 2003: guide for surveys using risk-based inspection for the offshore industry. ABS, December, 2003.

AMERICAN BUREAU OF SHIPPING. ABS 0132 : 2004: guidance notes for reliability-centered maintenance. ABS, July, 2004.

AHMAD, R.; KAMARUDDIN, S. An overview of time-based and condition-based maintenance in industrial application. Computers \& Industrial Engineering, v. 63, n.1, p. 135-149, aug. 2012.

AMERICAN PETROLEUM INSTITUTE. API RP 580: risk-based inspection. API Recommended Practice 580, 2nd ed. API, November, 2009.

AMERICAN PETROLEUM INSTITUTE. API RP 581: risk-based inspection technology. API Recommended Practice 581, 2nd ed. API, September, 2008.

ARUNRAJ, N.; MAITI, J. Risk-based maintenance - techniques and applications. Journal of Hazardous Materials, v. 142, n. 3, p. 653-661, Apr. 2007.

GOWID, S.; DIXON, R.; GHANI, S. Characterisation of major fault detection features and techniques for the condition-based monitoring of high-speed centrifugal blowers. International Journal of Acoustics and Vibration, v. 21, n. 2, 2016.

HU, H.; CHENG, G.; LI, Y.; TANG, Y. Risk-based maintenance strategy and its applications in a petrochemical reforming reaction system. Journal of Loss Prevention in the Process Industries, v. 22, n. 4, p. 392-397, July 2009.

INTERNATIONAL ELECTROTECHNICAL COMMISSION. IEC 60812:2006: Analysis techniques for system reliability - Procedure for failure mode and effects analysis (FMEA). 2nd ed. 2006-01, 2006.

INTERNATIONAL ORGANIZATION FOR STANDARDIZATION. ISO 13374-1:2003: condition monitoring and diagnostics of machines - data processing, communication and presentation - Part 1: general guidelines. ISO, 2003.

INTERNATIONAL ORGANIZATION FOR STANDARDIZATION. ISO 13623:2017: petroleum and natural gas industries - pipeline transportation systems. 3rd ed. ISO, 2017.

INTERNATIONAL ORGANIZATION FOR STANDARDIZATION. ISO 17776:2000: petroleum and natural gas industries - offshore production installations - guidelines on tools and techniques for hazard identification and risk assessment. ISO, 2000.

INTERNATIONAL ORGANIZATION FOR STANDARDIZATION. ISO 55000:2014: asset management - over- 
view, principles and terminology. ISO, 2014.

KARDEC, A.; ESMERALDO J.; LAFRAIA, J.; NASCIF, J. Gestão de Ativos. Rio de Janeiro: Qualitymark, 2014.

KHAN, F.; HADDARA, M. Risk-based maintenance (RBM): a quantitative approach for maintenance/inspection scheduling and planning. Journal of Loss Prevention in the process Industries, v. 16, p. 561-573, 2003.

OFFSHORE reliability data. 4th ed. SINTEF Industrial Management. OREDA, 2002.

PADMANABHAN, H. Condition based maintenance of rotating equipments on OSI PI platform - refineries/ petrochem plants. WCIR-Wipro Council for Industry Research, 2008.

QINGFENG, W.; WENBIN, L.; XIN, Z.; JIANFENG, Y.; QINGBIN, Y. Development and application of equipment maintenance and safety integrity management system. Journal of Loss Prevention in the Process Industries, v. 24, p. 321-332, 2011.

TELFORD, S.; MAZHAR, M.; HOWARD, I. Condition Based Maintenance (CBM) in the oil and gas industry: an overview of methods and techniques. In: INTERNATIONAL CONFERENCE ON INDUSTRIAL ENGINEERING AND OPERATIONS MANAGEMENT, 2., 2011, Kuala Lumpur, Malaysia. Proceedings [...]. Kuala Lumpur, Malaysia. IEOM, 2011.

THOM, F. C. M. Modelo de cálculo de risco dinâmico aplicado a compressores de gás. 2018. 299f. Tese (Doutorado em Engenharia Civil) - Escola de Minas, Universidade Federal do Ouro Preto, Ouro Preto, 2018.

Received: 16 December 2018 - Accepted: 3 September 2019. 